第 56 回 獣医疫学会学術集会

シンポジウム第一部“日本におけるジビェを取り巻く状況”

講演 1

野生鳥獣肉の安全性確保に関する厚生労働省の取組

小島三奈*

厚生労働省医薬・生活衛生局食品監視安全課

\title{
Risk Management Policy of the Ministry of Health, Labour and Welfare for Ensuring Safe Wild Game Meat
}

\author{
Mina KOJIMA* \\ Food Inspection and Safety Division, Pharmaceutical Safety and Environmental Health Bureau, \\ Ministry of Health, Labour and Welfare
}

\section{Summary}

With regard to countermeasures to prevent damage to farm crop by wild animals, e.g. deer and boar, usage of them as meat has been promoted. No hygiene control is applied for them on their feed and health, and therefore they have risk of contamination with a variety of pathogens, such as Hepatitis E virus and Trichinella spp.. The Ministry of Health, Labour and Welfare of Japan takes various measures to ensure the food safety of game meat - development and implementation of the Guidelines on Hygiene Management for Game Meat, measures to prevent it from contamination with radioactive substances and application of hygiene management along with HACCP to game meat processors.

\section{はじめに}

近年の農作物等の野生鳥獣被害防止対策の推進により, シカやイノシシ等の野生鳥獣の捕獲数が年々増加傾向にあ る一方で, 捕獲鳥獣を地域資源として捉え, 食肉（いわゆ る「ジビエ」) 等に有効活用しょうとする取り組みが全国 各地に広まりつつある。野生鳥獣の食肉としての利用を推 進するためには, 各方面において, その需要開拓・創出に 取り組むとともに，需要に応じた供給体制の確保と円滑な 流通を可能とする体系整備が必要となるが, それは食品と しての安全性の確保が大前提となる。食品として提供する ため野生鳥獣の処理等を業として営もうとする者は, 食品 衛生法に基づき, 都道府県知事等より食肉処理業の営業許

\footnotetext{
連絡先：小島三奈*

厚生労働省医薬・生活衛生局食品監視安全課

干100-8916 東京都千代田区霞が関 1-2-2

Tel : 03-3595-2337; Fax : 03-3503-7964

E-mail : kojima-mina@mhlw.go.jp
}

可を受け，同法や条例に基づく衛生管理を遵守し，自らの 責任において処理, 出荷する野生鳥獣肉の安全性の確保に 努める責務がある。

厚生労働省においては, 平成 26 年, 狩猟から販売まで の衛生管理をカバーする「野生鳥獣肉の衛生管理に関する 指針 (ガイドライン)」(以下,「厚生労働省ガイドライン」 とする。）を策定し, 自治体においては, 厚生労働省ガイ ドラインを参考にしつつ, 地域における関係事業者に対す る指導が行われている。また, 野生鳥獣肉の安全確保に関 しては, 放射性物質污染への継続的な対応や新たに HACCP 制度化に向けた対応等が必要となっている。

\section{食品安全行政の全体像}

食品衛生行政はリスク評価, リスク管理, リスクコミュ ニケーションの 3 要素からなる, リスクアナリシスの原則 に従い実施されている。厚生労働省は, リスク管理機関の 一つとして, 都道府県等の自治体, 農林水産省, 消費者庁 等とともに, 食品の安全性確保のための施策を担っている。 
表 1 野生鳥獣の病原体保有状況（平成 28 年度厚生労働科学研究報告より）

\begin{tabular}{|c|c|c|c|}
\hline & 病原体 & 保有率 & 検査部位 \\
\hline \multirow[t]{4}{*}{ イノシシ } & E 型肝炎ウイルス & $2.1 \%(16 / 774)$ & 血液 \\
\hline & 住肉胞子虫 & $25.0 \%$ & 筋肉 \\
\hline & 肺吸虫 & $25.0 \% \quad(6 / 24)$ & 肺 \\
\hline & カンピロバクター属菌* & $14.2 \%(30 / 211)$ & 糞便 \\
\hline \multirow[t]{3}{*}{ シカ } & 腸管出血性大腸菌 & $16.3 \%(50 / 306)$ & 粪便 \\
\hline & 住肉胞子虫 & $76.9 \% \quad(10 / 13)$ & 筋肉 \\
\hline & カンピロバクター属菌* & $5.2 \%(16 / 306)$ & 蕒便 \\
\hline
\end{tabular}

また，施策の実施に当たっては，リスク評価機関である食 品安全委員会の食品健康影響評価を科学的根拠とし, 消費 者や食品等事業者を含めた関係者との間のリスクコミュニ ケーションを行い，その意見を施策に反映している。

食品衛生法（昭和 22 年 12 月 24 日法律第 233 号）は, 公衆衛生の見地から必要な措置を講じ，飲食に起因する衛 生上の危害の発生を防止し，国民の健康の保護を図ること を目的とし，食品（同法に扔いて医薬品及び医薬部外品を 除く全ての飲食物と定義）を規制対象として，人の健康を 損なう恐れがある食品の販売等の禁止, 食品の規格基準の 策定, 食品の監視指導の実施等を定めている。

平成 30 年 6 月に食品衛生法の改正が行われ, 食品の種 類や施設規模等にかかわらず一律の衛生管理基準の遵守を 求める制度を改め, 国際基準である $\mathrm{HACCP}^{\text {注 } 1)}$ に沿って, 個々の事業者が自ら衛生管理計画を作成して記録すること により，衛生管理を「見える化」して取り組むこととした (HACCP に沿った衛生管理の制度化)。本制度は令和 2 年 6 月 1 日から施行され，その後， 1 年間の経過措置期間を 経て, 令和 3 年 6 月 1 日から本格的に施行される。

HACCP に沿った衛生管理には, 大規模事業者, と畜場 及び大規模の食鳥処理場を対象として, HACCP の 7 原則 に基づき，事業者自らが，使用する原材料や製造方法等に 応じ，計画を作成し，管理を行う「HACCP に基づく衛生 管理」と, 小規模な事業者等を対象とし, 各業界団体が作 成する手引書を参考に，簡略化されたアプローチによる衛 生管理を行ってもよいとする「HACCP の考え方を取り入 れた衛生管理」がある。

「HACCP の考え方を取り入れた衛生管理」のために業

注 1) HACCP (Hazard Analysis and Critical Control Point) : 食品 等事業者自らが食中毒菌污染や異物混入等の危害要因（ハ ザード）を把握した上で，原材料の入荷から製品の出荷 に至る全工程の中で, それらの危害要因を除去又は低減 させるために特に重要な工程を管理し，製品の安全性を 確保しようとする衛生管理の手法。
界団体が手引書を作成する際には，厚生労働省が業界団体 と事前相談や意見交換を行い, 専門家による食品衛生管理 に関する技術検討会でその内容を確認した上で，自治体に 通知するとともに，厚生労働省のホームページ上に公開し ている。

野生鳥獣肉の処理については，一般社団法人日本ジビエ 振興協会が「小規模ジビエ処理施設向けの HACCP の考え 方を取り入れた衛生管理のための手引書」を作成・普及し ており，これらの取組により，今後の野生鳥獣肉の安全性 の向上が期待される ${ }^{1)}$ 。

\section{野生鳥獣の病原体保有状況と 野生鳥獣肉を原因とする食中毒の発生状況}

野生鳥獣は，牛や豚等の家畜とは異なり，飼料や健康状 態等の管理が行われていないことから，人に対する病原体 を保有している可能性が高く, 食品として, 一定のリスク が存在する。厚生労働科学研究「野生鳥獣由来食肉の安全 性の確保とリスク管理のための研究」に扔いて, シカ, イ ノシシ等の野生鳥獣が保有する病原体の実態調查を実施し ており， E 型肝炎ウイルス，病原性大腸菌，サルモネラ属 菌, カンピロバクター属菌, 旋毛虫 (トリヒナ), 肺吸虫 等が含まれていたことが明らかになっている。（表 1)

野生鳥獸肉の摂食による食中毒については, 平成 8 年か ら令和元年の間に，食中毒として自治体から厚生労働省に 報告された件数は 11 件であるが, 寄生虫や $\mathrm{E}$ 型肝炎など の家畜由来の食肉には通常見られない食中毒が含まれてい ることに注意が必要である。(表 2)

(1) E 型肝炎ウイルス

$\mathrm{E}$ 型肝炎の感染事例は, 検查方法の確立等の影響もあり, 近年報告数が増加している 物, 特に豚レバー, シカ, イノシシ等の肉の加熱を徹底す ることが重要であり, 厚生労働省では, 野生鳥獣肉や豚レ バーなどの食品は十分に加熱調理を行うょう注意喚起を 行っているほか， E 型肝炎に関する Q\&A をホームページ 
表 2 野生鳥獣肉を原因とした食中毒事例（食中毒統計平成 8 年〜令和 2 年 7 月)

\begin{tabular}{cccc}
\hline 年 & 原因食品 & 原因物質 & 患者数 \\
\hline 平成 9 年 & シカ肉 & 腸管出血性大腸菌 & 4 \\
\hline 平成 12 年 & シカ肉 & サルモネラ & 9 \\
\hline 平成 13 年 & シカ肉 & 腸管出血性大腸菌 & 3 \\
\hline 平成 15 年 & シカ肉 & E 型肝炎ウイルス & 4 \\
\hline 平成 17 年 & イノシシ肉 & E 型肝炎ウイルス & 1 \\
\hline 平成 21 年 & シカ肉 & 腸管出血性大腸菌 & 1 \\
\hline 平成 21 年 & シカ肉 & 不明 & 5 \\
\hline 平成 28 年 & クマ肉 & 旋毛虫 (トリヒナ) & 21 \\
\hline 平成 30 年 & クマ肉 & 旋毛虫 (トリヒナ) & 3 \\
\hline 平成 30 年 & シカ肉 & 不明 & 3 \\
\hline 令和元年 & クマ肉 & 旋毛虫 (トリヒナ) & 9 \\
\hline
\end{tabular}

にて公表し, 逐次内容の更新を行っている ${ }^{2)}$ 。また, 平成 15 年にシカ肉の生食を原因とする食中毒発生時には, 自 治体に対し, 野生動物の肉等の生食は避けること, 特に $\mathrm{E}$ 型肝炎ウイルスは妊婦に感染すると劇症肝炎を発症し, 死 亡する率が高いという研究結果を踏まえ, 妊婦は特に野生 動物の生の肉等の摂食を控えるべきであることを周知する よう依頼した。

(2) 腸管出血性大腸菌

腸管出血性大腸菌は野生鳥獣肉からも検出されている。 その食中毒事例は重症化する場合があり, 平成 29 年度に おいても 1 名の死者を伴う事例が発生している。発生防止 には, 原材料の加熱や殺菌, 手洗い等の一般衛生管理の徹 底が重要であり, 厚生労働省では, 生食用牛肉の規格基準 の設定や, 食肉の十分な加熱調理について注意喚起等を 行っている。

（3）カンピロバクター属菌

カンピロバクター食中毒は細菌性食中毒による年間発生 件数の約 $60 \%$ を占め, その多くが生又は加熱不十分な食 肉, 特に鷄肉の提供を原因とする。厚生労働省では, 䳕肉 を中心に, 流通過程において加熱用である旨の情報提供を 行うことの周知や，十分に加熱して䀧食するようリーフ レット等により注意喚起を行っている。

\section{（4）旋毛虫（トリヒナ）}

平成 28 年 12 月に, 荻城県においてローストクマ肉を原 因食品とする旋毛虫（トリヒナ）食中毒が発生した。本事 例では, 狩猟されたヒグマが食肉処理業の許可を受けた施 設ではなく狩猟仲間により解体され，その肉を譲り受けた 飲食店が客に加熱不十分な状態で提供していた。本事例を
受けて厚生労働省は, 自治体に対し, 野生鳥獣肉は十分加 熱して喫食すること, まな板や包丁など使用する器具を使 い分け, 処理終了毎に洗浄, 消毒し, 衛生的に保管するよ う指導を依頼した。

\section{厚生労働省ガイドラインに従った衛生管理の推進}

（1）厚生労働省ガイドラインの概要

前述のような野生鳥獣肉による食中毒の発生を防止する ため, 平成 26 年に作成した厚生労働省ガイドラインにお いては, 野生鳥獣肉を取り扱う者が, 食用に供される野生 鳥獣肉の安全性を確保するための必要な取り組みとして, 狩橅から処理, 食肉としての加工・調理・販売, 消費に至 るまで, 野生鳥獸肉の安全性確保を推進するという基本的 な考元方を示し, 狩猟者や野生鳥獣肉を取り扱う食肉処理 業等の関係者が共通して守るべき衛生措置を盛り込んでい る。また, 食品衛生法に基づく HACCP に沿った衛生管理 及び営業許可の取得とその施設基準を遵守することが, 衛 生措置実施のベースとなっている。(図)

厚生労働省ガイドラインは, 不特定または多数の者に野 生鳥獣肉を供与する者等を対象とするが, 食中毒の発生防 止のため, 自家消費に伴う処理を行う者も参考とすること が可能である。

厚生労働省に扔いては，厚生労働省ガイドラインに規定 する衛生管理が遵守されているかについて, 自治体を通じ, 施設の自己申告による調查を実施している。令和元年度の 調查結果によると, 異常が認められた個体の廃衰等の措置 については実施されている傾向にあるものの, その一方で, 食肉への病原体の污染源となる消化管内容物や粪便による 


\section{野生鳥獣肉の衛生管理に関するガイドライン}

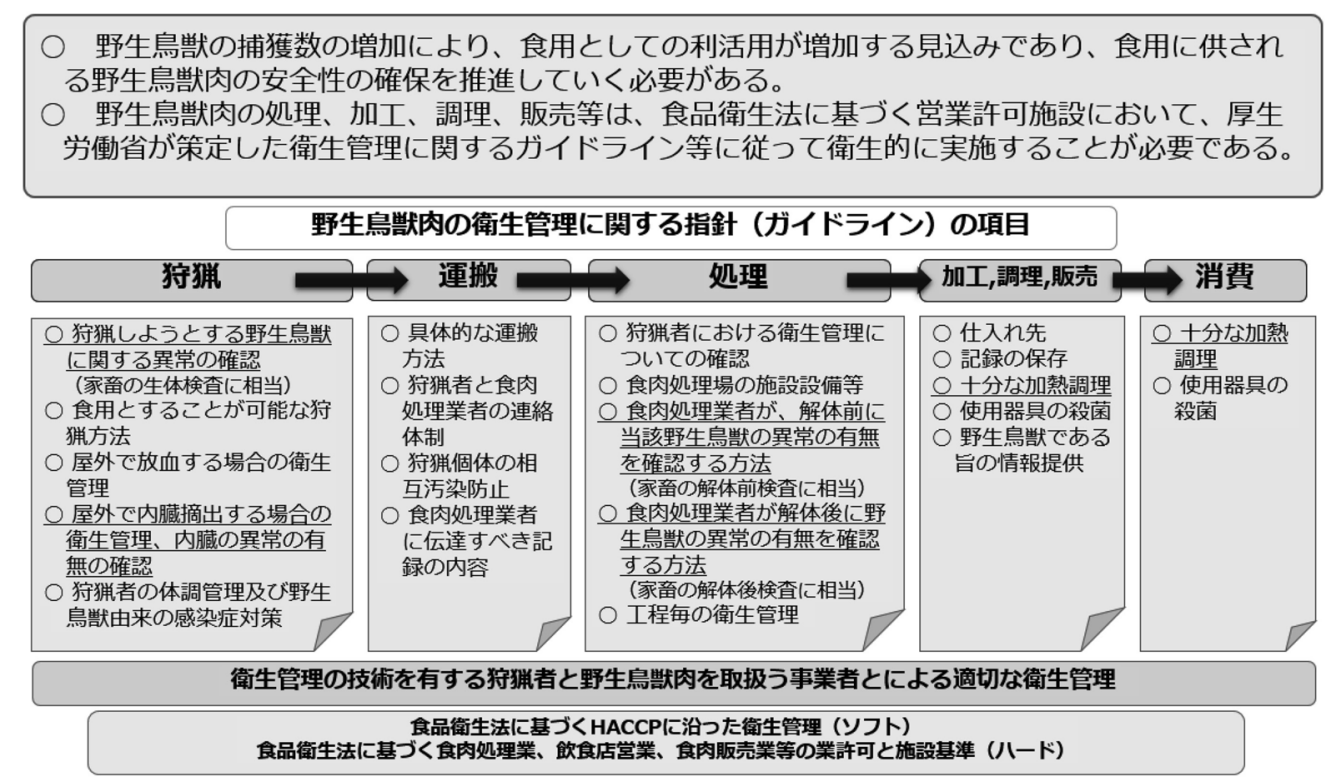

図 野生鳥獣肉の衛生管理に関するガイドラインの概要

污染を防止するために重要な衛生管理手法である食道や肚 門の結さつ処理については改善の必要がある。(表 3, 表 4)

厚生労働省ガイドラインは, 食道及び肛門の結さつ方法, はく皮方法, トリミング方法など, 食肉の污染防止及び除 去ための具体的な手順を定めている。

厚生労働ガイドラインについては, 令和 2 年 5 月, 食品 衛生法の改正内容を反映する改正を行った。主な改正点は 以下のとおりである。

・野生鳥獣肉を処理する食肉処理施設についても HACCP に沿った衛生管理を実施する必要があることを明記

- 処理施設の施設設備に関する衛生管理は, 食品衛生法施 行規則第 66 条の 2 第 1 項, 別表第 17 の 2 から 6 に定め る, 施設設備の衛生管理, 使用水の管理, ねずみ及び昆 虫対策並びに廃棄物並びに排水の取扱いに関する基準を 遵守することを明記

厚生労働省ガイドラインは, 厚生労働省ホームページに て公表されているので参照いただきたい5)。

(2) 自動車で野生鳥獣を解体する食肉処理業の施設基準ガ イドライン

近年, 野生鳥獣の食肉としての利活用が推進される中, 食肉処理施設が近隣にない地域における衛生的な処理等を 目的として, 必要な設備等を備えた移動式解体処理車の開 発及び普及が進められている。厚生労働省では, 平成 30 年 3 月に, 自動車で野生鳥獣を解体する食肉処理業の施設 基準ガイドラインを策定し, 移動式解体処理車において野 生鳥獣を解体するために必要となる, 剥皮場所, 処理室,
懸肉室，給水給湯設備，排水設備等の設置及びその構造等 の条件を示している注2)。

\section{野生鳥獣肉の放射性物質対策}

東日本大震災の発生以来，関係自治体において，原子力 災害対策本部より示された「検査計画, 出荷制限等の品目・ 区域の設定・解除の考え方」(原子力災害対策本部決定) に基づき，食品中の放射性物質の検查計画が策定され，同 計画に基づき検査が行われている。基準值を超過した食品 は回収・廃棄等の措置がとられるほか，基準值を超過する 食品に地域的な広がりが認められる場合には，原子力災害 対策本部長により出荷制限等の指示が出されることによ り，その流通を未然に防止している。厚生労働省では，検 查対象の自治体に対し，検查計画の策定及び検査の実施を 通知し，自治体が実施した検查の結果を取りまとめ，全て 公表している4)。

野生鳥獣肉の放射性物質の近年の検査状況については, イノシシ，クマ，シカ肉等に対して重点的な検査が実施さ れている。事故から 10 年が近くなる中にあっても, 徐々 に減少してはいるが他の食品と比較して基準值超過の割合 が多い (平成 30 年度の基準值超過の割合 $7.8 \%$ ) $^{3)}$ 。野生鳥 獣肉の出荷制限が設定されている一部の自治体において

\footnotetext{
交) 本ガイドラインについては，示されている施設基準が食 品衛生法第 54 条により厚生労働省令で定める, 都道府県 が参酌する基準として規定されたため, 令和 3 年 6 月 1 日以降廃止にする予定。
} 
表 3 厚生労働省ガイドラインの遵守状況（実施率の高い／低い項目）

\begin{tabular}{c|l|l}
\hline & \multicolumn{1}{|c|}{ 実施率の高い項目 } & \multicolumn{1}{c}{ 実施率の低い項目 } \\
\hline (1) & 異常が認められた個体は搬入せず廃棄 $(99.9 \%)$ & 定期的な細菌検查の実施 $(37.7 \%)$ \\
\hline (2) & 廃棄時の機械器具の洗浄消毒 $(98.7 \%)$ & 金属探知の実施 $(39.2 \%)$ \\
\hline (3) & 枝肉等の速やかな摂氏 10 度以下への冷却 $(98.4 \%)$ & 疾病・異常排除の記録 $(56.8 \%)$ \\
\hline
\end{tabular}

出典：令和元年度野生鳥獣の衛生管理等に関する実態調査結果

※実施率：自己点検による実施率

表 4 厚生労働省ガイドラインの遵守状況（調査項目ごとの実施率（一部抜粋））

\begin{tabular}{|c|c|c|}
\hline \multicolumn{3}{|l|}{ 消化管内容物からの污染防止 } \\
\hline \multicolumn{2}{|l|}{ 放血後の食道の結さつ又は閉そく処理 } & $72.5(\%)$ \\
\hline \multicolumn{2}{|c|}{$\begin{array}{l}\text { 肛門を合成樹脂製の袋で覆い，直腸を肛門の近くで結さつするとともに，肛門部による個体 } \\
\text { の污染を防ぐこと。 }\end{array}$} & $69.7(\%)$ \\
\hline \multirow{2}{*}{$\begin{array}{l}\text { 個体に接触するナイフ等の器具は, } 1 \text { 頭処理するごとまたは污染された都度, } \\
\text { 摂氏 } 83 \text { 度以上の温湯などにより洗浄・消毒すること。 }\end{array}$} & 放血時 & $94.6(\%)$ \\
\hline & はく皮時 & $95.5(\%)$ \\
\hline
\end{tabular}

出典：令和元年度野生鳥獣の衛生管理等に関する実態調查結果

※実施率：自己点検による実施率

は，処理加工施設において解体する野生鳥獣全頭について 放射性物質の検查を行い, 基準值以下のものに限定して出 荷を行う体制を構築することにより, 出荷制限の一部を解 除している。野生鳥獣は家畜のような飼養管理ができず, 除染されていない地域を中心に生息しており，今後も引き 続き検査を行い，野生鳥獸肉の放射性物質污染状況の動向 を調べていく必要がある。

\section{おわりに}

今後, 野生鳥獣肉の利活用が推進されていく中，食品と しての安全性の確保を利活用の大前提として, 野生鳥獣肉 を取り扱う関係者において必要な衛生管理や取り組みが進 められることが必要である。厚生労働省においては，今後 も引き続き, 自治体や関係省庁・団体と連携して, 野生鳥 獣肉の衛生管理に関する施策に取り組んでいくこととして いる。

\section{引用文献}

1）一般社団法人日本ジビエ振興協会 : 小規模ジビエ処理 施設向けの HACCP の考え方を取り入れた衛生管理の ための手引書, 厚生労働省, 東京, 2019. Available at： https://www.mhlw.go.jp/content/11130500/000653709.pdf (Accessed January 7, 2021)

2）厚生労働省：E型肝炎ウイルスの感染事例・ E 型肝炎 Q\&A. Available at : https://www.mhlw.go.jp/houdou/2003/ 08/h0819-2a.html (Accessed January 7, 2021)

3）厚生労働省：食品中の放射性物質の対策と現状につい て．平成元年度食品に関するリスクコミュニケーショ ン〜食品中の放射性物質対策に関する意見交換会〜資 料 2. Available at: https://www.mhlw.go.jp/content/ 11131500/000607000.pdf (Accessed January 7, 2021)

4）厚生労働省 : 月別検査結果. Available at : https://www. mhlw.go.jp/stf/kinkyu/0000045250.html (Accessed January $7,2021)$

5）厚生労働省：野生鳥獣肉の衛生管理に関する指針（ガ イドライン). Available at: https://www.mhlw.go.jp/content/ 11130500/000635324.pdf (Accessed January 7, 2021)

6) 国立感染症研究所感染症疫学センターウイルス第二部: 最近の $\mathrm{E}$ 型肝炎の増加について（2016 年 4 月 27 日現 在). IASR, 37, 134-136, 2016. Available at : https://www. niid.go.jp/niid/ja/hepatitis-a-m/hepatitis-a-iasrd/6616-437 d02.html（Accessed January 7, 2021） 